\title{
LECTURA Y CONSAGRACIÓN EN EL HONDERO ENTUSIASTA DE PABLO NERUDA
}

Jaime Gamboa Goldemberg Universidad Nacional, Costa Rica

\section{I}

Basta una somera revisión de la crítica nerudiana para constatar el sitio marginal que se ha asignado a El hondero entusiast $^{1}$ dentro de la producción lírica del poeta. En apariencia, esta marginalidad ha obedecido a motivos circunstanciales, ligados a la opinión del propio Neruda en cuanto a mantener el poemario inédito durante más de diez años. Sin embargo, se puede replicar que la historia de la literatura conoce muchos casos de obras cuya consagración se realiza pese a la oposición de sus autores.

Esta acotación nos conduce a preguntas pertinentes para la historiografía literaria: ¿de qué modo operan los mecanismos de consagración de las obras?; ¿ hasta dónde ciertos autores han logrado conducir su propia crítica, al punto de manejar hasta los detalles del decorado en el panteón de sus obras?; ¿ de qué forma se superponen las lecturas y hasta qué punto una primera lectura autorial deja migas que conducirán al mismo sitio a los lectores venideros?

1. Pablo Neruda, El hondero entusiasta y otros poemas (Buenos Aires: Torres Agüero Editor, 1974); en adelante, El hondero. 
Entre las dos principales actividades posibles de un lector (leer o no leer), la lectura nerudiana de El hondero, expresada en su «Advertencia» preliminar, resulta una velada invitación a ignorar, a no pasar más allá2; es un anatema estructural dirigido al lector. Pero también, para aquel lector o lectora, osada o curiosa, que decida descender a esa "verdad olvidada", aquel autor-lector primero, inventor y descubridor a la vez, toma el papel de Virgilio oficioso y hace de la lectura una visita al museo.

Parece que una vez preferido el trabajo de leer al trabajo de ignorar (labores que otorgan su dinámica específica -con el perdón de Saussure por el calco - a la vida de las obras en el seno de la vida social), podemos perfilar otras dos posibilidades, menos discutidas: se puede leer lo escrito o se puede, en cambio, leer una lectura.

Normalmente la pantalla traslúcida, la prelectura que se interpone entre texto y lector, es obra de los críticos y otros agentes institucionales; sin embargo, por su naturaleza, una prelectura autorial, y muy especialmente una que aparece integrada al artefacto-libro, casi como parte del texto literario mismo, pertenece a otra categoría y presenta un interés particular. En las páginas siguientes indagaremos el carácter de esta mediación en El hondero y trataremos de proponer algunas ideas en torno al Lector, las lecturas y la consagración o marginación de las obras dentro del campo literario.

2. Transcribimos a continuación el texto de la «Advertencia»: "Los poemas recogidos en este libro forman parte de un ciclo de mi producción desarrollada hace ya cerca de diez años. La influencia que ellos muestran del gran poeta uruguayo Carlos Sabat Ercasty y su acento general de elocuencia y altivez verbal me hicieron sustraerlos en su gran mayoría a la publicidad. Ahora, pasado el período en que la publicación de El hondero entusiasta me hubiera perjudicado íntimamente, los he entregado a esta editorial, como un documento, válido para aquellos que se interesan en mi poesía. El libro original contenía un número mucho mayor de composiciones que, si faltan en este cuaderno, es porque se extraviaron para siempre. También, muchas de las que aquí aparecen, van inconclusas, con pedazos de menos, fragmentos caídos al roce del tiempo, perdidos. Me hubiera gustado poseer todos los versos de este tiempo sepultado, para mí prestigiado del mismo interés que nimba las viejas cartas, ya que este libro no quiere ser, lo repito, sino el documento de una juventud excesiva y ardiente. No he alterado ni agregado ni suprimido nada de estos versos renacidos, he querido preservar su autenticidad, su verdad olvidada". 
La lectura es una noción plural que emerge, a la vez, del texto literario y del contexto sociohistórico de la recepción, y sus huellas marcan significativamente los paratextos más variados. No se trata solo de aislar un lector implícito, o de identificar los múltiples comportamientos de lectores "empíricos", sino de abarcar ambas perspectivas dentro de una noción integradora. Se busca examinar la forma en que el texto condiciona o, en cierto modo, "prescribe" una lectura, y a la vez examinar la forma en que una o varias lecturas condicionan la recepción del texto. A diferencia de Blanchot, para quien "la lecture n'est pas une conversation", la literatura siempre implica diálogo, y que en ese diálogo la voz del lector no puede verse más como una constante fijada en el texto, sino más bien como una ecuación que demuestra, entre otras cosas, la forma en que funciona esa máquina constante de producción de sentidos, que es la literatura.

\section{II}

Cuando Neruda inserta una «Advertencia» que precede al texto poético, evidentemente no se dirige a una instancia lectora "interna" (como podría ser el destinatario de los poemas). El anatema autorial busca prevenir a un receptor que se coloca en otro nivel, se dirige a un lector hipotético que debe interpretar y juzgar el texto y que, de algún modo, es "exterior" a este. Visto así, el comple jo de normas, la poética que da sustento a las imágenes, cada verso, sílaba o acento, apuntan también a ese otro nivel, al nivel de la decodificación adecuada supuesta por el texto. Ese es el nivel del Lector que el poemario postula a partir de su constitución estética. Se trata, por tanto, de un lector ideal, un lector modelo (Eco) o lector implícito (Iser); un decodificador ideal de un texto cuya codificación es el resultado de una práctica significante que, en cuanto tal, representa siempre una respuesta, afirmativa o de ruptura (de mímesis y transgresión, diría Gómez Moriana), frente a sistemas de normas vigentes (Vodicka). En esa dinámica de afirmación y ruptura el texto porta, o más bien construye, 
su(s) interpretación(es) posible(s). Por ejemplo, en El hondero se puede proponer un Lector Ideal que debe captar e interpretar adecuadamente la transformación de una serie de códigos y subcódigos, como veremos a continuación.

En relación con lo estilístico, tanto el metro como la rima presentan secuencias y combinaciones particulares que acentúan una serie de semejanzas y diferencias con respecto a los tópicos formales del modernismo.

He visto tendido frente a los mares del sur, arrollarse las aguas y extenderse inconteniblemente

fatalmente

en las mañanas y al atardecer

(«Es como una marea...»)

Bajo un aparente versolibrismo se reorganizan isometrías típicas de la poesía modernista (alejandrinos, endecasílabos). La rima, en tanto, no puede llamarse tal, pues toma las características de un procedimiento anafórico menos rígido que, aunque anunciado por Darío, tendría en las vanguardias su expresión más generalizada. Algo similar ocurre con la relación entre las formas versales y el nivel sintáctico: por un lado, en la mayoría de los poemas, verso y oración se refuerzan mutuamente; y, por otro, no es difícil advertir una suerte de disgregación del componente sintáctico: los sintagmas (nominales, adverbiales, etc.) cobran sentido en sí mismos, representan unidades al margen de, o en contraste con, las unidades oracionales.

Estos rasgos estilísticos bastan para mostrar que desde los más elementales niveles del texto se construye un Lector Ideal que, sin ser un lector "vanguardista", tampoco es el "modernista". Los códigos modernistas, e incluso ciertos rasgos románticos filtrados por el modemismo, forman labase principal de la que parte la transgresión. Así, en el nivel semánticoencontramosalgunos enfoques ya francamente vanguardistas, 
por ejemplo, la manera en que es tratada la isotopía de la destrucción o de la desintegración del yo (como en el poema «Llénate de mí...»). Junto a estos, encontramos poemas que no se distancian significativamente del erotismo modernista (como «Amiga, no te mueras...»).

Todo ello apunta a cimentar una percepción del poemario como un texto-en-proceso, en el que el Lector es una categoría textual e histórica, una inferencia que es posible hacer a partir de la información que el texto suministra y de la situación de las instituciones literarias en los momentos de su producción y publicación. Como ha dicho Lotman, el lector es otro texto y, por eso mismo, ignora los límites entre texto y contexto.

\section{III}

Al desconocer los límites, el Lector prolonga el texto. La manera más común de realizar esta prolongación es anexándole nuevos textos, llenando de nuevos mensajes la atmósfera textual. Estos nuevos mensajes generados por el Lector se convierten así en prelecturas dirigidas a otro lector.

Toda lectura es una nueva escritura del texto. Claro está que se trata de una reescritura limitada por las posibilidades estructurales: es una traducción (al igual que toda traducción es una lectura). Señalar que la reescritura está limitada es sólo otra manera de plantear que el texto "construye" a su Lector; pero tal instancia construida tiene el cometido de interpretar, esto es: reescribir. Al construir su Lector el texto invoca, desde su constitución misma, la participación del agente capaz de realizar un número de interpretaciones, si no infinito, al menos suficiente para garantizarle cierto lapso de "vida" y cierto lugar en el universo de los textos. De ahí que haya libros para el día, "best-sellers" pobres en lecturas, que no logran sobrevivir más allá del juicio retroalimentado de cierto lector contemporáneo; así como hay libros milenarios, cuyas "extensiones" sobrepasan en mucho sus páginas, libros que siguen convocando, cada día, nuevas lecturas; 0 , lo 
que es igual, generando nuevos textos. Entre esos dos polos hay infinidad de posiciones, y también hay movimiento.

En El hondero, el vínculo entre lectura y consagración aparece de forma bastante nítida en la «Advertencia» supracitada y en una «Nota» con otras opiniones de Neruda, incluida en la edición que hemos empleado. Ambos textos hacen notar la superposición de varias lecturas y su nexo con la consagración o marginación de la obra literaria.

En torno a lo primero, Neruda da testimonio de una lectura inicial, propia, según la cual el libro era un "trabajo en el que había puesto lo más original de lo esencial mío", e incluso lo remite a otro escritor esperando "que el poeta me lanzaría una ininterrumpida serie de elogios por lo que yocreía una verdadera obramaestra dentro de los límites de mi poesía" ${ }^{3}$. Ese otro poeta-lector es Carlos Sabat Ercasty, quien le responde que, "sin hipocresía alguna, hallaba que ese poema tenía la influencia de Sabat Ercasty". La lectura de Ercasty, con la autoridad institucional de que estaba investida en ese momento, impresiona al joven Neruda, al extremo de que decide dejar el poemario inconcluso e inédito. Diez años después, "pasado el período en que la publicación me hubiera perjudicado íntimamente", Neruda da a la publicidad el poemario, pero le agrega la «Advertencia». A su vez, los editores amplían de nuevo el texto, años después, añadiendo la «Nota».

El libro que circula, entonces, está mediado por, al menos, cuatro lecturas: Neruda 1, Ercasty, Neruda 2, y Editores. Son lecturas que han dejado marcas específicas en el texto que leemos. Esas marcas, quizá las más notorias, repercuten en las lecturas sucesivas y producen un espectro aún mayor de marcas, menos palpables. Sin duda, la decisión de no publicar el texto,

3. Estos y otros fragmentos corresponden a la «Nota» incluida en la edición que utilizamos; por su extensión, no se incluye aquí en forma completa. 
acto surgido de la segunda lectura de Neruda —originada a su vez en la lectura de Ercasty - es una marca fundamental. De hecho, ocurrió que un lector privilegiado (Neruda) impidió la interpretación contemporánea del texto, impidió su consumo en calidad de obra "actual", y con ello interpuso una condición que repercutiría en su recepción posterior. Si a ello agregamos los juicios relativos a la "influencia" de Ercasty (léase: la falta de originalidad), el carácter "documental" e inconcluso, según el cual el libro es sólo el portador de una "verdad olvidada", se observan claros esfuerzos del autor-lector por delimitar las lecturas ulteriores.

Entonces, ciertas condiciones básicas de la lectura de El hondero fueron dadas por una superposición de lecturas iniciales. Estas generaron una porción agregada de sentido que no era parte del texto original. En tomo al libro se forma un campo, un campo de sonidos y silencios que constituye la condición fundamental de lectura del libro para un lector de, pongamos por caso, 1993: se trata de un subproducto, de una rareza sin mayor repercusión, de una estrella menor en la constelación nerudiana. La marginalidad del texto se ha confeccionado en ese espacio que lo circunda y que lo hace ser lo que es.

La clave de nuestra tesis es que el texto literario es un dispositivo lingüístico cuya estructura existe para ser interpretada, para ser leída. Es en esa dimensión que el texto exige un lector, de quien espera y para quien produce una competencia. Pero esa competencia implica a su vez la capacidad del lector para interpretar, para reescribir el texto. Así, el ciclo se abre y la obra literaria "vive" de una determinada manera, según sea la calidad, cantidad y tipo de lecturas que sea capaz de generar históricamente. Según este punto de vista, no hay más textos-objeto, y mucho menos se puede restringir el estudio del Lector al análisis de ciertas estructuras apelativas "inmanentes". Un texto literario no apela a (no habla para) una instancia hipotética inscrita en el papel, más bien dialoga, genera otros discursos, actúa sobre seres 
humanos que realizan lecturas históricas, condicionadas por las estructuras del campo literario. Estas breves notas sobre El hondero entusiasta expresan también, entonces, nuestro interés por mostrar la huella que esos seres humanos, a quienes hemos uniformado bajo la denominación de Lector, imprimen en el texto, iniciando con su génesis, con la presencia de la institución en las matrices mismas de la actividad creadora, y prolongándose a lo largo de toda la trayectoria textual. En ese juego de cajas chinas, cada nuevo lector siempre puede encontrar algo nuevo, algo distinto o no dicho antes, pero puede que su hallazgo sea sólo una meta provisoria en un trayecto de sentido abierto por otros lectores, meta que será llevada más allá por el lector que acecha a sus espaldas. 